HALL, E. R. (1952). J. gen. Microbiol. 7, 350-357.

\title{
Investigations on the Microbiology of Cellulose Utilization in Domestic Rabbits
}

\author{
By ELIZABETH R. HALL \\ Department of Bacteriology and Public Health, The State College of \\ Washington, Pullman, Washington, U.S.A.
}

SUMMARY : Cellulolytic iodophilic cocci have been isolated in significant numbers from rabbit caecal contents. Seven strains of the anaerobic Gram-positive cocci have been isolated on seven separate occasions from rabbits obtained from different sources and maintained on various diets. No other cellulolytic bacteria have been observed in cultures inoculated with high dilutions of caecal contents, suggesting that the isolated cocci are the most important agents of cellulose digestion in the caecum.

Of the carbohydrates tested the caecal cocei utilize only cellulose and cellobiose. The products of cellulose fermentation include acetic acid, succinic acid, a trace of formic acid, ethanol, $\mathrm{CO}_{2}$ and $\mathrm{H}_{2}$.

It is generally accepted that the primary digestion of cellulose in herbivorous mammals is accomplished by micro-organisms indigenous to the host. The demonstration by Elsden, Hitchcock, Marshall \& Phillipson (1946) of volatile fatty acids in the rumen of cattle and sheep and the isolation of rumen cellulolytic bacteria in significant numbers (Hungate, 1950) substantiate this concept. A similarity between the mechanism of cellulose digestion in ruminants and rabbits is suggested by the presence of volatile fatty acids in rabbit caecal contents as shown by Elsden et al. (1946) and by the results of direct microscopic examination of rabbit caecal contents by Baker \& Martin (1937), who reported that various morphological types of bacteria were active in the disintegration of plant cell walls in the rabbit caecum.

The present investigation was undertaken in order to provide experimental evidence concerning the cultural and physiological characteristics of the cellulolytic bacteria found in the rabbit caecum.

\section{EXPERIMENTAL}

\section{Culture methods}

The culture methods employed in the isolation of cellulose-digesting bacteria from the caecum of domestic rabbits were similar to those used by Hungate (1950) in his studies of mesophilic anaerobic cellulose-decomposing bacteria. The basic culture medium contained the following final percentages $(w / v)$ of ingredients: $\mathrm{NaCl}, 0.025 ;\left(\mathrm{NH}_{4}\right)_{2} \mathrm{SO}_{4}, 0.01 ; \mathrm{K}_{2} \mathrm{HPO}_{4}, 0.02 ; \mathrm{KH}_{2} \mathrm{PO}_{4}, 0.01$; $\mathrm{CaCl}_{2}, 0.003 ; \mathrm{MgSO}_{4} .7 \mathrm{H}_{2} \mathrm{O}, 0.003 ; \mathrm{NaHCO}_{3}, 0.5$; sodium thiolacetate, 0.02 or L-cysteine monohydrochloride, $\mathbf{0} \cdot \mathbf{0 1}$. Either cotton or filter-paper cellulose in the form of a fine suspension was added in concentration of $0 \cdot 1-0 \cdot 2 \%(\mathrm{w} / \mathrm{v})$ in liquid and $0.6 \%(\mathrm{w} / \mathrm{v})$ in agar media. Rumen fluid or caecal extract in a concentration of $20-30 \%(\mathrm{v} / \mathrm{v})$ was included in all culture media. Triple 
distilled water was used to bring the total volume of the culture medium to $100 \mathrm{ml}$. The medium minus $\mathrm{NaHCO}_{3}$ was prepared and sterilized in $200 \mathrm{ml}$. Florence flasks. After sterilization, the $\mathrm{NaHCO}_{3}$ solution which had been sterilized by filtration, was added and the medium transferred to sterile rubberstoppered tubes. The final $\mathrm{pH}$ value of the medium was $6 \cdot 8-7 \cdot 1$. Anaerobiosis was maintained during preparation and transfer of the medium by passing oxygen-free $\mathrm{CO}_{2}$ or $\mathrm{N}_{2}$ through it and the receiving tubes.

The inoculum consisted of caecal contents removed immediately after killing the rabbit with ether. The entire caecum was removed, weighed, and the contents stripped into a flask containing 50-100 ml. of sterile basal culture medium. After mixing the caecal contents with the diluent, serial dilutions were made into both liquid and solid cellulose media. The weight of caecal contents was determined by the difference between the original weight of the caecum and its weight after being stripped.

Pure cultures of the cellulolytic cocci were obtained from agar cultures of high dilution by picking a colony with a glass capillary pipette and transferring it to a tube of melted and cooled rumen fluid cellobiose agar. The colony was broken against the side of the tube and mixed with the agar, serial dilutions were then made into four or five tubes of the same medium. When discrete colonies were apparent in the cellobiose agar cultures, a period of 4 or 5 days incubation being required, a colony was picked and diluted serially into similar medium. After at least two transfers on cellobiose agar, in which only one colony type was observed in tubes of high dilution, the culture was considered to be pure. The cellulolytic activity of the pure culture was verified by inoculating liquid and solid cellulose media with a single colony from the cellobiose culture. Liquid dilution series and parallel agar series showed cellulose digestion at about the same dilutions. Pure cultures of the cellulosedigesting cocci were also obtained from liquid cellulose cultures inoculated with high dilutions of caecal contents. Stock cultures of the caecal cocci were maintained on cellulose agar. Cultures used in physiological studies were obtained by inoculating cellulose liquid media with colonies picked from cellobiose agar.

\section{Characteristics of the isolated cocci}

Morphologically, the caecal cellulolytic cocci isolated on seven separate occasions were similar. On primary isolation and in liquid cultures they appear as short-chain streptococci or diplococci. After prolonged cultivation on solid media the majority of the cells are in diplo- or micrococcus arrangements. Young cultures ( $48 \mathrm{hr}$.) are Gram-positive, but as the cultures age, the cells become Gram-rariable. The cells of both old ( 7 days) and young cultures are iodophilic.

In primary cultures of the caecal cocci more rapid growth occurs in liquid than in solid cellulose media. In liquid cultures an incubation period of 7-20 days at $38^{\circ}$ is necessary for complete disappearance of cellulose in the highest dilutions showing cellulose digestion. In agar cultures 23-78 days incubation is required before distinct zones of clearing, indicating cellulose 
digestion, are detected. Pure cultures of the cocci digest cellulose more rapidly than mixed cultures. An appreciable digestion of cellulose in liquid cultures occurs as soon as $\mathbf{2 4} \mathrm{hr}$. after inoculation and in solid media diffuse zones of clearing can be noted after 4 or 5 days' incubation. Pure cultures inoculated into cellobiose agar show colonies after $48 \mathrm{hr}$. incubation. The subsurface colonies on this medium are less wrinkled and larger than those on cellulose agar. No pigment has been observed.

The isolated caecal cocci are strict anaerobes, no growth being observed in cultures in which resazurin is not reduced to the colourless form. The optimum temperature for growth is $38-40^{\circ}$. No growth occurs at $45^{\circ}$ and only very slow growth at $32^{\circ}$. Maximum decomposition of cellulose is evident in cultures in which the $\mathrm{pH}$ value is adjusted within the range of $6 \cdot 6-7 \cdot 1$.

Nutrient requirements. Various substrates were tested for their ability to support growth of the caecal cocci in a medium which contained neither rumen fluid nor caecal extract. The following substances were tested: ascitic fluid (Difco), peptone (Difco), yeast extract (Difco), phytone (Baltimore Biological Laboratories; BBL), and trypticase soy broth (BBL). These substances were tested singly and in various combinations and, in some instances, rabbit serum in a concentration of $2 \%(\mathrm{v} / \mathrm{v})$ was also added to the medium. A medium containing $0 \cdot 1 \%(\mathrm{w} / \mathrm{v})$ phytone, yeast extract, peptone and $2 \%(\mathrm{v} / \mathrm{v})$ rabbit serum plus the basal inorganic salt solution supported growth when inoculated with $0.2 \mathrm{ml}$. from the rapidly growing liquid cellulose culture. However, subcultures from these tubes to a similar medium failed to show growth. When this medium was inoculated with a single colony from cellobiose agar no growth occurred, although a $5 \%(\mathrm{v} / \mathrm{v})$ rumen fluid medium inoculated in a similar manner showed active cellulose digestion after 5 days' incubation. Ability of the phytone + yeast extract + peptone + serum medium to support growth in the initial culture was attributed to the rumen fluid carried over in the liquid inoculum. No substitute for rumen fluid or caecal extract has been found to support consistent growth of the caecal cellulolytic cocci.

Carbohydrate utilization. Ability of the caecal cocci to utilize various carbohydrates was tested. Sterile basal medium consisting of inorganic salt solution $\left(\mathrm{NaHCO}_{3}\right.$ decreased to $\left.0 \cdot 1 \%\right)$ and $30 \%(\mathrm{v} / \mathrm{v})$ rumen fluid was inoculated with a $48 \mathrm{hr}$. liquid cellulose culture, the amount of inoculum being sufficient to give a final concentration of $0.5 \%(\mathrm{v} / \mathrm{v})$. A gas mixture of $95 \% \mathrm{~N}_{2}$ and $5 \% \mathrm{CO}_{2}$ was bubbled through the medium at the time of transferring in order to maintain anaerobic conditions. The inoculated medium was transferred to sterile tubes and the carbohydrate solutions were added to each tube in sufficient quantities to give a concentration of $0.25 \%$. All of the carbohydrate solutions were sterilized by filtration. One set of tubes was incubated at $38^{\circ}$, and another set held at refrigerator temperature to serve as controls. Basal medium containing no carbohydrate, but inoculated and incubated, served as a control for possible fermentable substances present in the rumen fluid. Utilization of the substrate was determined by turbidity and acid production. In addition to cellulose the following carbohydrates were tested: rhamnose, L-arabinose, L-xylose, D-xylose, fructose, glucose, 
mannose, galactose, trehalose, cellobiose, sucrose, maltose, lactose, raffinose, dextrin, inulin, starch, glycerol, salicin, dulcitol, sorbitol and inositol. of these substrates only cellobiose was utilized.

\section{Fermentation products}

Culture methods. Culture techniques used were similar to those employed by Hungate (1944). The culture flasks were of $100 \mathrm{ml}$. capacity with a glass sealed inlet and outlet. The basal culture medium contained inorganic salts (see culture methods) plus $20 \%(\mathrm{v} / \mathrm{v})$ rumen fluid. Filter-paper cellulose, in the form of a fine suspension, was added in concentrations of from 0.1 to $0 \cdot 3 \%(\mathrm{w} / \mathrm{v})$; cellobiose was added in a concentration of $0 \cdot 1 \%(\mathrm{w} / \mathrm{v}) . \mathrm{L}-\mathrm{Cysteine}$ monohydrochloride $(0.4 \%)$ was used as reducing agent. During the preparation and inoculation of the medium anaerobic conditions were maintained by the passage of oxygen-free gas through the medium. Nitrogen was used in all experiments with the exception of the cellobiose experiments in which $\mathrm{CO}_{2}$ was used. The inoculum was $2-5 \mathrm{ml}$. of a 24 or $48 \mathrm{hr}$. liquid cellulose culture $/ 50 \mathrm{ml}$. culture medium. The medium, after inoculation, was transferred aseptically to the culture flasks through the inlet side arm which was then sealed in a flame. The outlet arm was attached by means of pressure tubing to a vacuum pump and evacuated until the medium boiled vigorously. 'The outlet was then sealed in the flame. Incubation was for 10 days or 2 weeks at a temperature of $38^{\circ}$. Control flasks were similar to the experiment except that they were held at refrigerator temperature. After incubation, the flasks, control and experimental, were analysed for $\mathrm{CO}_{2}, \mathrm{H}_{2}$, rolatile acids, nonvolatile acids, ethanol, glycerol and reducing substances.

Analytical methods. The amount of cellulose fermented was determined by the dry-weight difference between the residue of the experimental and control flasks. Gas analyses were done with the Haldane apparatus. The dissolved $\mathrm{CO}_{2}$ was liberated by acidification of the culture with dilute sulphuric acid and absorbed by ascarite. The quantity of gas liberated was determined by the weight increase of the ascarite absorption tubes. Ethanol was determined by dichromate oxidation of the neutral distillate. The acid produced from the oxidized ethanol was removed by steam distillation and the nature and quantity determined by a Duclaux distillation. The volatile acids were separated by partition chromatography in a silica gel column (Elsden, 1946) and the quantity of each estimated from Duclaux distillations. Succinic acid was determined manometrically with a succinoxidase preparation from mammalian heart muscle (Umbreit, Burris \& Stauffer, 1945). The method of Friedemann, Cotonio \& Shaffer (1927) was used to determine lactic acid. Qualitative tests for reducing substances were negative.

Results. Analyses were run in duplicate, a control flask being run simultaneously with its corresponding experimental flask. Gas analyses were performed only for those experiments in which cellulose was the substrate. Results obtained in all experiments were essentially the same, and no significant differences were observed between the products formed from cellulose and those from cellobiose. The fermentation products included ethanol, acetic 
acid, succinic acid, a trace of formic acid, $\mathrm{CO}_{2}$ and $\mathrm{H}_{2}$. In one cellulose experiment lactic acid was produced. Propionic and butyric acid were never found in concentrations significantly greater than in the controls. Tests for glycerol (Amerine \& Dietrich, 1943) were negative in two separate experiments. Results of a typical cellulose fermentation analysis are expressed in Table 1. A comparison of the non-gaseous fermentation products of cellulose and cellobiose are found in Table 2 .

\begin{tabular}{|c|c|c|c|}
\hline End-products & $\begin{array}{c}\text { Cellulose } \\
\text { control } \\
\text { (mg. atoms C) }\end{array}$ & $\begin{array}{c}\text { Cellulose } \\
\text { experimental } \\
\text { (mg. atoms C) }\end{array}$ & $\begin{array}{c}\text { Difference } \\
\text { (mg. atoms C) }\end{array}$ \\
\hline Ethanol & - & $0 \cdot 3$ & $0 \cdot 3$ \\
\hline Formic acid & - & Trace & - \\
\hline Acetic acid & $1 \cdot 32$ & 1.62 & $0 \cdot 3$ \\
\hline Propionic acid & 0.50 & 0.51 & 0.01 \\
\hline Butyric acid & $0 \cdot 42$ & $0 \cdot 40$ & - \\
\hline Lactic acid & 0.08 & 0.08 & - \\
\hline Succinic acid & -- & 0.23 & 0.23 \\
\hline $\mathrm{CO}_{2}$ & 0.007 & 0.54 & 0.533 \\
\hline $\mathrm{H}_{2} \dagger$ & -- & - & - \\
\hline
\end{tabular}

Table 2. Non-gaseous fermentation products of cellulose* and cellobiose* by caecal coccus strain $F-6$

$\begin{array}{lcc}\text { End-products } & \begin{array}{c}\text { Cellulose } \\ \text { (mg. atoms C) }\end{array} & \begin{array}{c}\text { Cellobiose } \\ \text { (mg. atoms C) }\end{array} \\ \text { Ethanol } & 0 \cdot 55 & 0 \cdot 45 \\ \text { Formic acid } & \text { Trace } & \text { Trace } \\ \text { Acetic acid } & \mathbf{0 . 2 6} & 0.34 \\ \text { Propionic acid } & - & - \\ \text { Butyric acid } & - & - \\ \text { Succinic acid } & 0.71 & 0.64\end{array}$

* Substrate utilized : cellulose $94 \mathrm{mg}$., cellobiose $100 \mathrm{mg}$.

\section{DISCUSSION}

Cellulolytic cocci can be consistently isolated in significant numbers; 500 thousand to 72 million/g. moist caecal contents, from domestic rabbits fed diets of dehydrated alfalfa hay, Larro pellets, $\ddagger$ Friskies dog food $\S$ plus oats, or cracked barley plus alfalfa hay (Table 3). Successful isolations of the caecal cellulolytic cocci have been made on seven separate occasions during a period of $2 \frac{1}{2}$ years. The rabbits from which these isolations were made came from different sources and were obtained at different times throughout the experimental period. These facts suggest that the cellulose-digesting cocci were not chance inhabitants of the adult rabbit caecum but rather members of the normal microflora (Table 3).

\$ Larro Green Pellets for Rabbits, minimum per cent: crude protein, 15; crude fat, 2; crude fibre, 19; crude ash, 7.75; moisture, 12; minerals, 1. General Mills Inc., Sperry Division, San Francisco, California.

$\S$ Friskies Dog Food, Albers Milling Co., Los Angeles, California. 
Table 3. Numbers of caecal cocci demonstrated from rabbits fed various diets

Diet

Larro pellets

Larro pellets

Larro pellets

Larro pellets plus grass cuttings

Friskies plus oats

Cracked barley plus alfalfa hay

Dehydrated alfalfa hay

Cracked barley*

\begin{abstract}
Number of caecal
cellulolytic cocci/g.

moist caecal contents
\end{abstract}

$$
\begin{aligned}
& 64 \text { million } \\
& 45 \text { million } \\
& 25 \text { million } \\
& 72 \text { million } \\
& 22 \text { million } \\
& 6 \text { million } \\
& 500 \text { thousand }
\end{aligned}
$$

* Seven unsuccessful isolation attempts.

Failure to isolate cellulose-digesting bacteria from the caecal contents of rabbits maintained on a cracked barley diet may have been due to inadequate culture techniques rather than to an absence of these organisms. These isolations were attempted at a time when the culture procedure had not yet been perfected and negative results are therefore not conclusive. However, diet may affect the numbers of cellulolytic bacteria in the rabbit caecum. Recent investigations of Baker, Nasr, Morrice \& Bruce (1950) indicate that the only carbohydrate fractions of cracked barley to reach the caecum of the rabbit would be those, such as the 'hemicelluloses' and 'celluloses', which resist the action of digestive enzymes of the rabbit. Analyses of the food and faeces of rabbits which had been maintained for 3 weeks on a cracked barley diet showed a very small amount of 'cellulose' in cracked barley and no utilization of this 'cellulose' by the rabbit. In fact, the weight of the cellulose fraction in the faeces of this animal was slightly higher than in the food consumed. The small quantity of 'cellulose' in cracked barley and the apparent inability of the rabbit to utilize this 'cellulose' suggests that a barley diet would not support a large cellulolytic flora in the caecum. Utilization of added cotton cellulose by rabbits fed the cracked barley + filter-paper diet ranged from

\begin{tabular}{|c|c|c|c|c|c|c|c|c|c|c|c|c|}
\hline & \multicolumn{3}{|c|}{$\begin{array}{l}\text { Rabbit I, cotton } \\
\text { cracked barley diet }\end{array}$} & \multicolumn{3}{|c|}{$\begin{array}{l}\text { Rabbit III, cotton } \\
\text { cracked barley diet }\end{array}$} & \multicolumn{3}{|c|}{$\begin{array}{l}\text { Rabbit IV, cotton } \\
\text { eracked barley diet }\end{array}$} & \multicolumn{3}{|c|}{$\begin{array}{c}\text { Rabbit II, cracked } \\
\text { barley diet }\end{array}$} \\
\hline & $\begin{array}{l}\text { Food } \\
\text { (g.) }\end{array}$ & $\begin{array}{l}\text { Faeces } \\
\text { (g.) }\end{array}$ & $\begin{array}{l}\text { Diff. } \\
\text { (g.) }\end{array}$ & $\begin{array}{l}\text { Food } \\
\text { (g.) }\end{array}$ & $\begin{array}{l}\text { Faeces } \\
\text { (g.) }\end{array}$ & $\begin{array}{l}\text { Diff. } \\
\text { (g.) }\end{array}$ & $\begin{array}{l}\text { Food } \\
\text { (g.) }\end{array}$ & $\begin{array}{l}\text { Faeces } \\
\text { (g.) }\end{array}$ & $\begin{array}{l}\text { Diff. } \\
\text { (g.) }\end{array}$ & $\begin{array}{c}\text { Food } \\
\text { (g.) }\end{array}$ & $\begin{array}{c}\text { Faeces } \\
(\mathrm{g} .)\end{array}$ & $\underbrace{\text { Diff. }}_{(\mathrm{g} .)}$ \\
\hline Weight & 1050 & 367 & 683 & 1049 & 385 & 664 & 925 & 313 & 612 & 792 & 152 & 640 \\
\hline $\begin{array}{l}\text { Wt. sol. alco.-benzol } \\
\text { diastase-water }\end{array}$ & 541 & 23 & 518 & 540 & 26 & 514 & 476 & 19 & 457 & 462 & 20 & 442 \\
\hline $\begin{array}{l}\text { Wt. sol. } 2 \% \mathrm{H}_{2} \mathrm{SO}_{4} \\
\text { 'hemicellulose' }\end{array}$ & 79 & 39 & 40 & 79 & 45 & 34 & 69 & 29 & 40 & 190 & 20 & 170 \\
\hline $\begin{array}{l}\text { Wt. sol. } 72 \% \mathrm{H}_{2} \mathrm{SO}_{4} \\
\text { cellulose }\end{array}$ & 353 & 252 & 101 & 352 & 267 & 85 & 311 & 205 & 106 & $66^{2}$ & 82 & -15 \\
\hline
\end{tabular}
24 to $34 \%$ (Table 4 ).

Direct microscopic examination of caecal contents used in culturing showed Gram-positive iodophilic cocci similar to those isolated in culture and to those referred to by Baker \& Martin (1937) as being active in the decomposition

Table 4. Comparison of the quantity of food fractions eaten with the quantity excreted 
of cellulose in the rabbit caecum. Direct counts of these cocci indicated they were present in higher numbers than were demonstrated by culture methods. Between 112 million and 2 billion $\left(2 \times 10^{9}\right)$ diplococci $/ \mathrm{ml}$. caecal contents were shown to be present as a result of direct counts, whereas the parallel culture counts showed 25-72 million diplococci/g. moist caecal contents. This discrepancy may be due to the presence of additional species of cocci having the same size and staining reactions as the cellulolytic coccus. However, the numbers of micro-organisms demonstrated by cultures are usually significantly less than those obtained by direct counts. This would be particularly true for cellulolytic organisms such as the coccus, which tend to cling to undigested particles in the caecum.

The products formed from cellulose fermentation by the caecal cocci are ethanol, acetic acid, succinic acid, a trace of formic acid, $\mathrm{CO}_{2}$ and $\mathrm{H}_{2}$. Acetic and succinic acid are found in highest concentration and approximately equal quantities. Of these non-gaseous fermentation products acetic acid has been reported as being present in rabbit caecal contents.

Analyses of rabbit caecal contents for volatile fatty acids by Elsden et al. (1946) showed the presence of acetic, propionic and butyric in the following percentages of the total fatty acid content: acetic, 78.25; propionic, $9 \cdot 3$; butyric, $\mathbf{1 2 \cdot 4 5}$. The production of significant amounts of acetic acid by the cocci isolated from the caecum favours the conclusion that the isolated caecal coccus is an important cellulose digester in the rabbit caecum. The difference between the products formed from the fermentation of cellulose by pure cultures of the caecal coccus and those occurring normally in the caecum may be attributed, in part, to the mixed flora and substrate of the caecum.

The relationship of the caecal cocci to previously described anaerobic cellulose-digesting cocci is interesting. Except for the absence of yellow pigment it is quite similar to Ruminococcus flavefaciens as described by Sijpesteijn (1951). Many of the characteristics of the caecal cocci resemble those of the rumen cocci (Hungate, 1950). Morphologically these organisms are quite similar. Most of them appear to be Gram-variable; young cultures show many Gram-positive cells, but older cultures show a predominance of Gram-negative forms. The loss of ability to retain the Gram stain may be influenced by the accumulation of fermentation products. On primary isolation the caecal cocci, as well as the rumen cocci, occur in long or short chain arrangements. After repeated subcultivation, especially on agar media, the organisms resemble micrococci. The rumen and caecal cocci are obligate anaerobes which fail to grow in a medium in which resazurin is not reduced to the colourless form. The majority of the rumen cocci and the caecal cocci utilize only cellulose and cellobiose as substrates. Also, many strains of these organisms will not grow in a medium that does not contain rumen fluid. With a few exceptions, fermentation products of the rumen and caecal cocci are similar. The morphological, cultural and biochemical similarities of these anaerobic, cellulolytic cocci suggest that they form a closely related group of bacteria. 
'The author wishes to thank Dr R. E. Hungate for his encouragement and helpful suggestions during the course of this work, which was submitted in partial fulfilment of the requirements for the Doctor of Philosophy degree, The State College of Washington.

\section{REFERENCES}

Amerine, N. A. \& Dietrich, W. C. (1943). Glycerol in wines. J. Ass. off. agric. Chem., Wash. 26, 408.

Baker, F. \& Martin, R. (1937). Some observations of the iodophile microflora of the caecum of the rabbit; with special regard to the disintegration of cell wall substances. Zbl. Bakt. (2 Abt.), 96, 18.

Baker, F., Nasr, H., Morrice, F., \& Bruce, J. (1950). Bacterial breakdown of structural starches and starch products in the digestive tract of ruminant and non-ruminant mammals. J. Path. Bact. 62, 617.

Elsden, S. R., Hitchcock, M. W. S., Marshall, R. A. \& Phillipson, A. T. (1946). Volatile acid in the digesta of ruminants and other animals. J. exp. Biol. 22, 191.

Elsden, S. R. (1946). The application of the silica gel partition chromatogram to the estimation of volatile fatty acids. Biochem. J. 40, 252.

Friedemann, T. E., Cotonio, M. \& Shaffer, P. A. (1927). The determination of lactic acid. J. biol. Chem. 73, 335.

Hungate, R. E. (1944). Studies on cellulose fermentation. I. The culture and physiology of an anaerobic cellulose-digesting bacterium. J. Bact. 48, 499.

Hungate, R. E. (1950). The anaerobic mesophilic cellulolytic bacteria. Bact. Rev. $14,1$.

SirpesteiJn, A. K. (1951). On Ruminococcus flavefaciens a cellulose-decomposing bacterium from the rumen of sheep and cattle. J. gen. Microbiol. 5, 869.

Umbreit, W. W., Burris, R. H. \& Stauffer, J. F. (1945). Manometric Techniques and Related Methods for the Study of Tissue Metabolism. Minneapolis, U.S.A.: Burgess Publishing Co.

(Received 29 April 1952) 